\title{
PROFIL LITERASI SAINS SISWA SMP DI KOTA GERUNG PADA TEMA PENCEMARAN LINGKUNGAN
}

\section{PROFILE OF SCIENTIFIC LITERACY OF JUNIOR HIGH SCHOOL STUDENT IN GERUNG CITY ON THE THEME OF ENVIRONMENTAL POLLUTION}

\author{
Fitri Andini*', A. Wahab Jufri dan Mahrus \\ Program Studi Pendidikan Biologi FKIP Universitas Mataram, Mataram, Indonesia \\ Email: fitriandini451@gmail.com
}

Diterima: 08 Juli 2020. Disetujui: 09 Juli 2020. Dipublikasikan: 30 September 2020

\begin{abstract}
Abstrak: Penelitian ini bertujuan untuk menentukan tingkat literasi sains siswa pada tema pencemaran lingkungan di SMP Gerung pada tahun 2019. Jenis penelitian ini termasuk penelitian deskriptif. Teknik pengambilan sampel yang digunakan dalam penelitian ini adalah Area Probability Sample dengan menggunakan sampel sebanyak 10.5\% atau 255 sampel dari 2135 populasi. Pengumpulkan data dalam penelitian ini menggunakan tes, wawancara, dan dokumentasi. Hasil penelitian menunjukkan sebagai berikut: (1) siswa SMPN memiliki keterampilan literasi dalam kategori sedang 64.09; (2) tingkat kompetensi dan desain inkuiri ilmiah memiliki skor rata-rata 57.30 di SMPN 5 Gerung, 55.07 di SMPN 3 Gerung, 53,10 di SMPN 1 Gerung. Tingkat literasi saintifik siswa dalam kompetensi menafsirkan data dan bukti secara ilmiah memiliki skor rata-rata 66,19 di SMPN 1 Gerung, 60.61 di SMPN 5 Gerung, 59.86 di SMPN 3 Gerung; dan (3) literasi sains siswa berdasarkan jenis kelamin menunjukkan siswa perempuan memiliki tingkat melek huruf yang lebih tinggi yaitu 65.22 dibandingkan dengan siswa laki-laki sebesar 59.55. Disimpulkan bahwa tingkat literasi sains siswa berada pada kategori sedang, dan siswa perempuan memiliki tingkat kemampuan literasi yang lebih tinggi dibandingkan dengan siswa laki-laki.
\end{abstract}

Kata Kunci: Literasi sains, pencemaran lingkungan, jenis kelamin, kemampuan literasi.

\begin{abstract}
This study aims to determine the level of scientific literacy of students on the theme of environmental pollution in SMP Gerung in 2019. This type of research is a descriptive study. The sampling technique used was area probability sample using $10.5 \%$ sample or 255 sample of 2.135 populations. Data collecting in this study uses tests, interviews, and documentation. The results showed as follows: (1) the SMPN students have literacy skills in the medium category of 64.09 ; (2) the level of competence and the design of scientific inquiry had an average score of 57.30 at SMPN 5 Gerung, 55.07 at SMPN 3 Gerung, 53.10 at SMPN 1 Gerung. The level of scientific literacy of students in the competence of interpret data and evidence scientifically have an average score of 66.19 at SMPN 1 Gerung, 60.61 at SMPN 5 Gerung, 59.86 at SMPN 3 Gerung; and (3) the scientific literacy of students based on gender shows female students have a higher literacy level of 65.22 compared to male students of 59.55. It concluded that the level of scientific literacy of students is in the medium category, and female students have a higher level of literacy ability compared to male students.
\end{abstract}

Keywords: Scientific literacy, environmental pollution, gender, literacy ability.

\section{PENDAHULUAN}

Kurikulum 2013 mengamanatkan guru mengembangkan materi pembelajaran yang disesuaikan dengan kebutuhan dan karakteristik sekolah dan daerah, sebab buku teks yang dilengkapi dengan buku guru yang tersedia bersifat minimal [2]. Pembelajaran sains diberikan keleluasaan dalam memilih model pembelajaran yang sesuai dengan pendekatan ilmiah dengan tetap mempertimbangkan karakteristik materi pembelajaran [1]. Esensi pembelajaran sains seharusnya dapat memberikan pengalaman belajar langsung dan bermakna yang dapat diterapkan dalam kegiatan sehari-hari oleh peserta didik, tidak sekedar untuk mengingat dan memahami konsep. Untuk mewujudkan pembelajaran yang bermakna tersebut, diperlukan sarana yang dapat diperoleh melalui literasi sains siswa yang bermanfaat terutama dalam kegiatan pemecahan masalah.

Kementerian Pendidikan dan Kebudayaan (Kemendikbud) merilis pencapaian kompetensi sains siswa melalui Programme for International Student Assessment (PISA) yang diikuti oleh 72 negara peserta yang tergabung dalam satu lembaga bernama Organisation for Economic Cooperation and Development (OECD) yang berkedudukan di Paris 
J. Pijar MIPA, Vol. 15 No.4, September 2020: 339-345 DOI: 10.29303/jpm.v15i4.1957

Perancis, menunjukkan kenaikan pencapaian pendidikan di Indonesia yang signifikan yaitu sebesar 22,1 poin. Hasil tersebut menempatkan Indonesia pada posisi ke empat dalam hal kenaikan pencapaian murid dibanding hasil survei sebelumnya pada tahun 2012, dari 72 negara yang mengikuti tes PISA.

PISA adalah studi literasi sains internasional yang mengevaluasi secara berkala sistem pendidikan di seluruh dunia setiap 3 tahun sekali pada anak-anak berusia 15 tahun. Penilaian tingkat dunia yang diselenggarakan tiga tahunan tersebut bertujuan untuk menguji performa akademis anak-anak sekolah yang berusia 15 tahun. Hasil tersebut yang menempatkan Indonesia pada posisi ke empat, yang membuktikan bahwa minat pada aspek kognitif dan afektif siswa dapat diterapkan untuk membangun kompetensi sains. Kedua aspek tersebut mampu membentuk siswa yang dapat membuat keputusan dalam situasi saat ini dan untuk masa depan dari literasi sains siswa [10].

Literasi sains merupakan kemampuan setiap individu dalam mengaplikasikan pengetahan dalam memecahkan masalah yang berkaitan dengan sains dan teknologi dalam kehidupan sehari-hari, seseorang yang memiliki literasi sains yang baik akan mengikutsertakan pertimbangan wacana tentang sains dan teknologi yang membutuhkan kompetensi untuk menjelaskan fenomena secara ilmiah, mengevaluasi dan mendesain penyelidikan ilmiah, serta menginterpretasi data dan bukti-bukti secara ilmiah [11]. Rendahnya hasil belajar sains ditengarai berhubungan dengan proses pembelajaran sains yang belum memberikan peluang bagi peserta didik untuk mengembangkan kemampuan bernalar secara kritis. Berikut merupakan beberapa penelitian yang menunjukan bahwa masih lemahnya kemampuan guru dalam mengimplementasikan proses dan kegiatan pembelajaran yang sesuai dengan hakikat sains.

Pembelajaran sains masih bercirikan transfer sains sebagai produk (fakta, hukum, dan teori) yang harus dihafalkan sehingga aspek sains sebagai proses dan sikap benar-benar terabaikan [8]. Hasil penelitian lainnya melaporkan bahwa pembelajaran tidak dikaitkan dengan konteks kehidupan nyata, pembelajaran jarang dimulai dari masalah-masalah actual [14]. Pembelajaran sains di sekolah dasar cenderung bertolak dari materi pembelajaran bukan dari tujuan pokok pembelajaran sains dan kebutuhan peserta didik, dan tindakan pembelajaran sains cenderung hanya mengantisipasi ujian $[17,18,19]$.

Literasi sains merupakan aspek penting yang bisa dijadikan bekal bagi generasi zaman sekarang dalam upaya untuk menghadapi perkembangan teknologi yang semakin canggih, terutama dalam hal
ISSN 1907-1744 (Cetak)

ISSN 2460-1500 (Online)

mengakses informasi. Literasi sains tidak hanya tuntutan bagi ilmuwan, tetapi juga penting dimiliki oleh semua kalangan, termasuk generasi zaman sekarang ini. Secara sederhana literasi sains dapat diartikan sebagai melek sains, baik dalam hal konsep maupun aplikasinya. Generasi sekarang ini harus bisa mengetahui dan memilah jenis informasi yang disesuaikan dengan lingkup dan bidangnya, sehingga diharapkan dapat mengkaji informasi mengenai isuisu kontekstual dan menerapkannya dalam kehidupan sehari-hari untuk mengatasi permasalahan pribadi dan masyarakat secara luas.

Pembelajaran yang menekankan pada pecapaian kemampuan literasi sains peserta didik sangat diperlukan karena peserta didik akan memiliki kemampuan mencari atau menentukan jawaban pertanyaan yang berasal dari rasa ingin tahu tentang fenomena alam, dan dapat mengidentifikasi isu-isu ilmiah yang mendasari keputusan ilmiah dan teknologi [9]. Adapun kompetensi literasi sains terdiri dari menjelaskan fenomena secara ilmiah, mengevaluasi dan mendesain penyelidikan ilmiah, serta menginterpretasi data dan bukti-bukti secara ilmiah [11].

Salah satu tema pada mata pelajaran IPA yang yang perlu dikaji dalam literasi sains yaitu tema pencemaran lingkungan. Pencemaran dapat terjadi karena akibat kegiatan manusia yang dapat dicegah dan dikendalikan apabila memiliki kesadaran dan kepedulian agar lingkungan tidak tercemar [13]. Literasi sains pada tema pencemaran lingkungan penting dikaji karena dengan adanya pembelajaran pencemaran lingkungan diharapkan siswa dapat memahami berbahayanya dampak pencemaran lingkungan dan memiliki etika serta moralitas dalam menjaga lingkungan. Selain itu, siswa dapat memperoleh pengetahuan dasar dan mengetahui permasalahan, sehingga dalam aplikasinya siswa dapat menjaga kelestarian lingkungan. Hasil penelitian Fitriani dkk [6] yang berjudul literasi sains siswa SMP di kota Bandung pada tema pencemaran lingkungan menunjukkan bahwa rata-rata capaian literasi sains di kota bandung adalah $46.27 \%$ yang termasuk kurang sekali. Berdasarkan uraian tersebut penulis melakukan penelitian dengan judul "Profil Literasi Sains Siswa SMP di Kota Gerung pada tema Pencemaran Lingkungan”.

\section{METODE PENELITIAN}

Jenis penelitian ini merupakan penelitian deskriptif dengan populasi berjumlah 2135 siswa. Teknik pengambilan sampel yang digunakan dalam penelitian ini adalah Area Probability Sample atau dengan memperhatikan area atau tempat populasi. Sampel yang diambil pada penelitian ini berjumlah 
255 siswa atau $10.5 \%$ populasi yang berasal dari 3 Sekolah yang ada di Gerung. Tiga sekolah tersebut adalah SMPN 1 Gerung, SMPN 3 Gerung, dan SMPN 5 Gerung.Teknik pengumpulan data yang digunakan dalam penelitian ini adalah dengan menggunakan tes, wawancara, dan dokumentasi. Untuk mendapatkan instrument tes yang dapat disebut baik dilakukan teknik analisis uji validitas, reliabilitas, daya beda dan tingkat kesukaran sehingga memperoleh 30 butir soal.

Instrumen tes berupa pilihan ganda dengan empat pilihan jawaban yang terdiri dari pertanyaanpertanyaan IPA yang berhubungan dengan tema pencemaran lingkungan yang memuat literasi sains untuk melihat tingkat kompetensi literasi sains siswa. Skor maksimal untuk keseluruhan item soal yaitu 100. Skor perolehan siswa kemudian dikonversi kedalam kategori literasi sains diadaptasi dari tabel kategori literasi Arikunto [3].

Tabel 1. Kategori Literasi Sains Siswa

\begin{tabular}{cc}
\hline Ketentuan & Kategori \\
\hline Nilai $>\bar{x}+\mathrm{SD}$ & Tinggi \\
$\bar{x}-\mathrm{SD} \leq$ Nilai $\geq \bar{x}+\mathrm{SD}$ & Sedang \\
Nilai $<\bar{x}-\mathrm{SD}$ & Rendah \\
\hline
\end{tabular}

\section{HASIL DAN PEMBAHASAN}

Tingkat kemampuan literasi sains dikategorikan menjadi 3 yaitu kategori yaitu: tinggi, sedang, dan rendah. Adapun kategori literasi sains siswa di kota Gerung dapat dilihat pada Gambar 1 sebagai berikut:

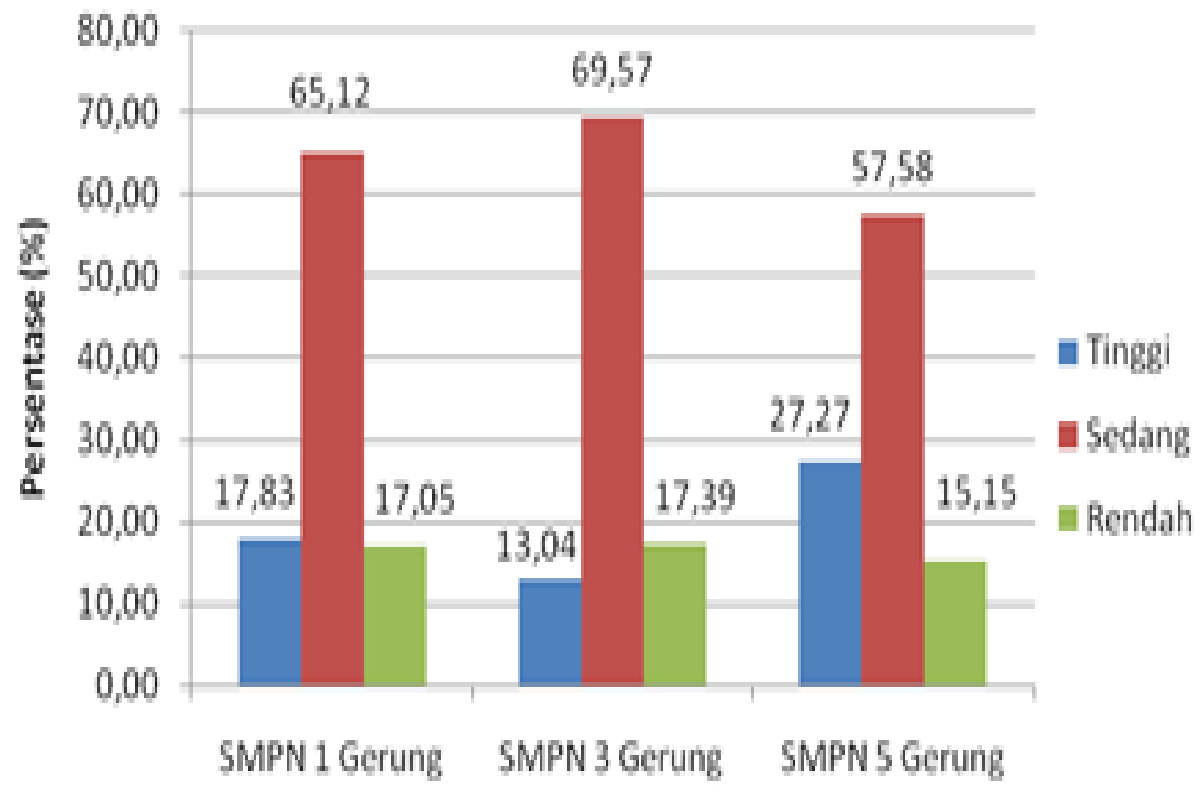

\section{Sekolah}

\section{Gambar 1. Tingkat Literasi Sains Siswa di SMPN Se-Kota Gerung}

Hasil penelitian menunjukkan bahwa kategori literasi sains siswa pada 3 sekolah di SMPN Kota Gerung termasuk kategori sedang dengan nilai rata-rata yang berbeda. Pada kategori sedang SMPN 1 Gerung, SMPN 3 Gerung, dan SMPN 5 Gerung memperoleh nilai rata-rata secara berurutan yaitu $65.12,69.57$, dan 57.58. Sedangkan pada kategori tinggi nilai rata-rata SMPN 1 Gerung, SMPN 3 Gerung, dan SMPN 5 Gerung secara berurutan sebesar 17.83, 13.04, dan 27.27. Pada kategori rendah SMPN 1 Gerung, SMPN 3 Gerung, dan SMPN 5 Gerung memperoleh nilai rata-rata pada kategori tinggi secara berurutan sebesar 17.05, 17.39, dan 15.15. Hal ini menunjukkan bahwa siswa di SMPN Gerung belum sepenuhnya melek sains. Menurut Winarti dkk [16], salah satu yang menyebabkan siswa belum sepenuhnya melek sains yaitu buku teks yang ada hanya memuat aspek pengetahuan saja dan tidak memiliki keseimbangan literasi sains. Selain itu menurut Fitriani dkk [6], siswa belum terbiasa mengerjakan soal-soal literasi sains yang berbentuk aplikasi yang berhubungan dengan materi yang menuntut kemampuan siswa 
J. Pijar MIPA, Vol. 15 No.4, September 2020: 339-345 DOI: 10.29303/jpm.v15i4.1957

dalam menganalisis untuk mengerjakan soal-soal tersebut. Sehingga kemampuan guru dalam mempersiapkan pembelajaran yang aktif sangat dibutuhkan untuk dapat mengoptimalkan kemampuan literasi saiins siswa.

Kemampuan literasi sains berdasarkan lokasi sekolah yang dianalisis yaitu terkait capaian kompetensi literasi sains di SMPN Se-Kota Gerung. Adapun tingkat kompetensi literasi sains siswa di SMPN 1 Gerung, SMPN 3 Gerung, dan SMPN 5 Gerung dapat dilihat pada Gambar 2 sebagai berikut:

Tingkat literasi sains siswa pada kompetensi menjelaskan fenomena secara ilmiah mempunyai persentase nilai rata-rata sebesar 63.18. Pada kompetensi menjelaskan fenomena secara ilmiah, nilai rata-rata yang diperoleh di SMPN 1 Gerung, SMPN 3 Gerung, dan SMPN 5 Gerung secara
ISSN 1907-1744 (Cetak)

ISSN 2460-1500 (Online)

berurutan yaitu sebesar $65.87,57.70$, dan 65.96 . Hal ini menunjukkan bahwa nilai tertinggi pada kompetensi menjelaskan fenomena secara ilmiah diperoleh oleh SMPN 5 Gerung, sedangkan nilai terendah diperoleh SMPN 3 Gerung.

Tingkat literasi sains siswa pada kompetensi mengevaluasi dan mendesain penyelidikan ilmiah mempunyai persentase nilai rata-rata sebesar 55.16. Pada kompetensi kedua ini nilai rata-rata yang diperoleh di SMPN 1 Gerung, SMPN 3 Gerung, dan SMPN 5 Gerung secara berurutan yaitu 53.1, 55.07, dan 57.30. Sehingga, dapat diketahui bahwa pada kompetensi mengevaluasi dan mendesain penyelidikan ilmiah nilai tertinggi diperoleh SMPN 5 Gerung, sedangkan nilai terendah diperoleh SMPN 3 Gerung.

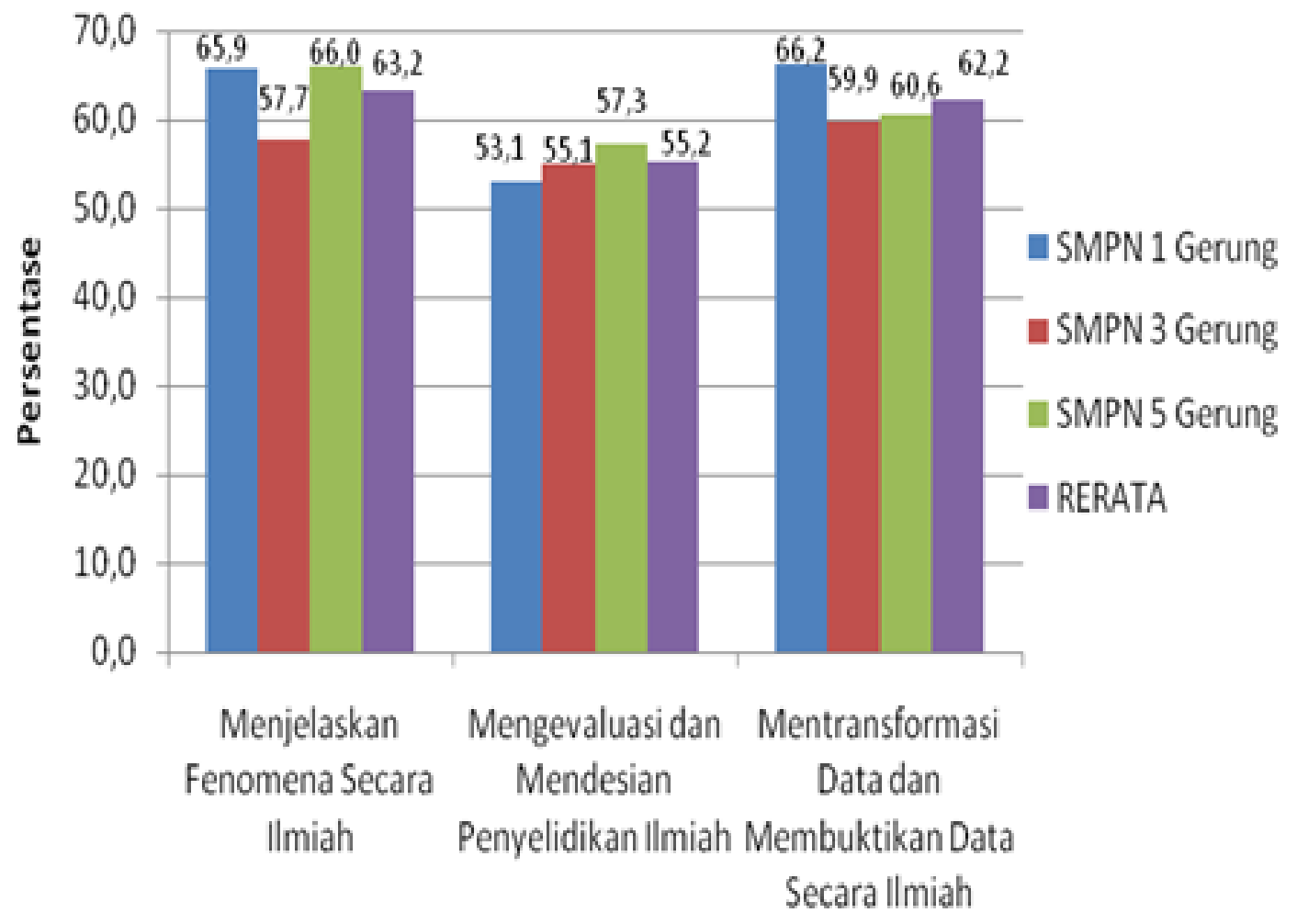

Kompetensi Literasi Sains

Gambar 2. Tingkat Kompetensi Literasi Sains Siswa di SMPN Se-Kota Gerung

Tingkat literasi sains siswa pada kompetensi menginterpretasi data dan bukti-bukti secara ilmiah mempunyai persentase nilai rata-rata sebesar 62.22 . Nilai rata-rata yang diperoleh pada kompetensi ketiga di SMPN 1 Gerung, SMPN 3 Gerung, dan SMPN 5 Gerung secara berurutan yaitu 66.2, 59.86 , dan 60.61. Hal ini menunjukkan bahwa nilai tertinggi pada kompetensi diperoleh SMPN 1 Gerung, sedangkan nilai terendah diperoleh SMPN 3 Gerung.

Rendahnya kemampuan siswa pada kompetensi mengevaluasi dan mendesain penyelidikan ilmiah menunjukkan bahwa siswa lebih mampu menjelaskan dan menafsirkan fenomena dibandingkan dengan mengevaluasi dan mendesain penyelidikan ilmiah. Menurut OECD [11] pada 
J. Pijar MIPA, Vol. 15 No.4, September 2020: 339-345

DOI: 10.29303/jpm.v15i4.1957

kompetensi mengevaluasi dan mendesain penyelidikan ilmiah merupakan salah satu kompetensi yang penting bagi siswa, karena pada aspek ini siswa dapat menggambarkan dan menilai penyelidikan ilmiah serta mengusulkan cara untuk menjawab pertanyaan secara ilmiah. Menurut Winarti dkk [16], salah satu penyebab rendahnya kemampuan siswa dalam mengevaluasi dan mendesain penyelidikan ilmiah yaitu pada buku teks yang kurang menyajikan permasalahan-permasalahan yang menuntut siswa untuk berpikir, dan kurang memunculkan strategi pemecahan masalah.

Gender atau jenis kelamin mempengaruhi kemampuan literasi sains siwa. Hal ini ditunjukkan juga pada hasil penelitian di SMPN Se-Kota Gerung. Tingkat kemampuan literasi sians berdasarkan gender di tiga SMPN di kota Gerung pada masing-masing kompetensi literasi sains dapat dilihat pada Tabel 2 yaitu sebagai berikut:

Hasil analisis kemampuan literasi sains berdasarkan gender di SMPN Se-Kota Gerung menunjukkan bahwa siswa perempuan mempunyai
ISSN 1907-1744 (Cetak)

ISSN 2460-1500 (Online)

kemampuan literasi yang lebih tinggi dibandingkan dengan siswa laki-laki. Nilai kemampuan literasi pada perempuan yaitu sebesar 65.22 , sedangkan pada laki-laki mempunyai nilai kemampuan literasi sebesar 59.55. Hal ini sesuai dengan penelitian Elvadola [5], bahwa terdapat perbedaan yang signiifikan antara kompetensi literasi sains antara siswa laki-laki dan siswa perempuan, siswa perempuan lebih unggul dibandingkan dengan lakilaki. Lebih unggulnya siswa perempuan daripada laki-laki dapat dilihat dari peringkat kelas. Menurut Srikandi dkk [12], berdasarkan hasil penelitiannya bahwa literasi sains perempuan lebih tinggi dibandingkan dengan laki-laki karena siswa perempuan lebih banyak belajar IPA dirumah sedangkan siswa laki-laki menghabiskan waktu di lingkungan sosial untuk bermain lebih banyak daripada perempuan. Hasil analisis terkait literasi sains berdasarkan gender di SMPN Se-Kota Gerung disajikan pada Tabel 3.

Tabel 2. Tingkat Kompetensi Literasi Sains Siswa Berdasarkan Gender di SMPN Se-Kota Gerung

\begin{tabular}{ccccccccc}
\hline \multirow{2}{*}{ Sekolah } & \multicolumn{2}{c}{$\mathrm{N}$} & \multicolumn{2}{c}{ MFSI } & \multicolumn{2}{c}{ MMPSI } & \multicolumn{2}{c}{ MDBBSI } \\
\cline { 2 - 9 } & $\mathrm{L}$ & $\mathrm{P}$ & $\mathrm{L}$ & $\mathrm{P}$ & $\mathrm{L}$ & $\mathrm{P}$ & $\mathrm{L}$ & $\mathrm{P}$ \\
\hline SMPN 1 Gerung & 62 & 67 & 69.8 & 71.4 & 55.2 & 57,9 & 68.6 & 72.9 \\
SMPN 3 Gerung & 42 & 51 & 58.1 & 59.3 & 54.2 & 55,7 & 54.6 & 65.7 \\
SMPN 5 Gerung & 16 & 17 & 65.1 & 67.1 & 61.3 & 61,2 & 60.9 & 62.5 \\
Jumlah & 120 & 135 & 193.0 & 197.8 & 170.6 & 174,8 & 184.1 & 201.1 \\
\hline
\end{tabular}

Tabel 3 Rekapitulasi Nilai Rata-Rata Literasi Sains Berdasarkan Gender di SMPN Se-Kota Gerung

\begin{tabular}{cccccccc}
\hline & \multicolumn{6}{c}{ Kemampuan Literasi } \\
\cline { 2 - 7 } & \multicolumn{5}{c}{ Laki-laki } & \multicolumn{5}{c}{ Perempuan } \\
\cline { 2 - 7 } Sekolah & $\mathrm{N}$ & $\bar{x}$ & & $\mathrm{SD}$ & $\mathrm{N}$ & $\bar{x}$ & SD \\
\hline SMPN 1 Gerung & 63 & 67.57 & 16.34 & 67 & 69.55 & 16.81 \\
SMPN 3 Gerung & 41 & 51.08 & 5.96 & 51 & 60.39 & 9.21 \\
SMPN 5 Gerung & 16 & 60.00 & 10.52 & 17 & 65.90 & 12.75 \\
Se-Kota Gerung & 120 & 59.55 & 14.49 & 135 & 65.22 & 14.47 \\
\hline
\end{tabular}

Rendahnya kemampuan literasi sains berdasarkan hasil wawancara dan analisis RPP guru yaitu kurangnya kemampuan siswa dalam mengembangkan perangkat pembelajaran terutama RPP yang didalamnya termasuk model pembelajaran Model pembelajaran discovery learning merupakan salah satu model pembelajaran yang berpengaruh signifikan terhadap kemampuan literasi sains peserta didik [15]. Beberapa hasil penelitian juga menunjukkan kategori literasi sains siswa SMP masih rendah, seperti penelitian yang dilakukan oleh Aryani, dkk [4] yang menunjukkan bahwa kemampuan literasi sains siswa SMPN Batu masih kurang dibawah 50\%, dimana persentasi literasi sains 
J. Pijar MIPA, Vol. 15 No.4, September 2020: 339-345 DOI: 10.29303/jpm.v15i4.1957

domain konten yaitu $36.67 \%$, domain procedural sebesar $35.83 \%$. Selain itu juga kategori literasi sains siswa SMP di kota Bandung pada tema pencemaran lingkungan masih rendah dengan rerata capaian keseluruhan sebesar $46.27 \%$ [7].

\section{KESIMPULAN}

Berdasarkan hasil penelitian dan pembahasan, dapat ditarik beberapa kesimpulan yaitu: tingkat kemampuan literasi sains siswa Se-Kota Gerung termasuk dalam kategori sedang dengan nilai ratarata yaitu 64,09. Tingkat literasi sains pada kompetensi menjelaskan fenomena secara ilmiah memiliki skor rata-rata berturut-turut yaitu 65,95 di SMPN 5 Gerung, 65,87 di SMPN 1 Gerung, dan 57,70 di SMPN 3 Gerung. Tingkat literasi sains siswa pada kompetensi mengevaluasi dan mendesain penyelidikan ilmiah memiliki skor rata-rata beruruturut yaitu 57,30 di SMPN 5 Gerung, 55,07 di SMPN 3 Gerung, dan 53,10 SMPN 1 Gerung. Tingkat literasi sains siswa pada kompetensi menginterpretasi data dan bukti-bukti secara ilmiah memiliki skor ratarata berurut-urut yaitu 66,19 di SMPN 1 Gerung, 60,61 di SMPN 5 Gerung, dan 59,86 di SMPN 3 Gerung. Siswa perempuan mempunyai kemampuan literasi yang lebih tinggi dibandingkan dengan siswa laki-laki, nilai kemampuan literasi pada perempuan yaitu sebesar 65,22, sedangkan pada laki-laki mempunyai nilai kemampuan literasi sebesar 59,55.

Saran yang dapat diberikan dalam penelitian ini yaitu: bagi peneliti selanjutnya, agar ditambah pengembangan instrument tes literasi sains untuk mengukur seluruh indikator pada setiap domain, sehingga kemampuan literasi sains terukur secara menyeluruh. Selain itu, bagi guru agar lebih mengembangkan perangkat pembelajaran.

\section{DAFTAR PUSTAKA}

[1] Afriana, J., Permanasari A., dan Fitriani, A. (2016). Penerapan Project Based Learning Terintegrasi STEM untuk Meningkatkan Literasi Sains Siswa Ditinjau dari Gender. Jurnal Inovasi Pendidikan IPA.2(2): 202-212.

[2] Ananda, R., dan Abdillah. (2018). Pembelajaran Terpadu (Karakteristik, Landasan, Fungsi, Prinsip, dan Model). Medan: Lembaga Peduli Pengembangan Pendidikan Indonesia.

[3] Arikunto, Suharsimi. (2010). Prosedur Penelitian Suatu Pendekatan Praktik. Jakarta: Rineka Cipta.

[4] Aryani, Ade Kirana., Suwono Hadi., dan Parno. (2016). Profil Kemampuan Literasi Sains Siswa SMPN 3 Batu.Prosiding Seminar Nasional Pendidikan IPA Pascasarjanan UM. Malang, Jawa Timur.
ISSN 1907-1744 (Cetak)

ISSN 2460-1500 (Online)

[5] Elvadola, C. (2016). Profil Kompetensi Literasi Sains Siswa Berdasarkan The Programme For International Student Assesment (PISA) Pada Konten Biologi Kelas IX SMP se-Kecamatan Kemiling di Bandar Lampung.Skripsi. Universitas Lampung.

[6] Fitriani, W., Hairida., dan Lestari, I. (2013). Deskripsi Literasi Sains Siswa dalam Model Inkuiri pada Materi Laju Reaksi di SMAN 9 Pontianak. Skripsi. Universitas Tanjungpura.

[7] Fitriani, N.H., Sari, I.M., dan Liliawati, W. (2016). Literasi Sains Siswa SMP Kota Bandung pada Tema Pencemaran Lingkungan. Semnas Pendidikan IPA Pascasarjana UM. 1(1)381-386

[8] Istyadji, M. (2007). Penerapan Panduan Model Pembelajaran Learning Cycle dengan Kooperatif Group Investigation untuk Meningkatkan Kualitas Proses dan Hasil Belajar Siswa SMA pada Materi Pokok Larutan Elektrolit dan Non Elektrolit. Universitas Negeri Malang.

[9] Kusuma, A.Y. (2016). Literasi Sains Dalam Pembelajaran IPA. E-Journal. (7)3B: 69

[10] OECD. (2013). PISA 2012 Result: What Students Know and Can Do-Student Performance in Mathemathics, Reading and Science. PISA: OECD Publishing.

[11]OECD. (2017). PISA 2015 Assessment and Analytical Framework: Science, Reading, Mathematic and Financial Literacy. PISA.

[12] Srikandi, M.M., Sujana, A., dan Aeni, N. (2017). Pengaruh Pembelajaran Kontekstual Terhadap Kemampuan Literasi Sains Berbasis Gender pada Materi Sistem Pencernaan. Jurnal Pena Ilmiah. 2(1): 661-670.

[13] Sumampouw, O.J. (2015). Diktat Pencemaran Lingkungan. Manado: Sam Ratulagi University.

[14] Suroso. (2012). Penerapan Model Pembelajaran Kontekstual dalam Meningkatkan Keterampilan Proses dan Hasil Belajar Sains Siswa Kelas V $S D$ No 5 Bandung. Skripsi. Universitas Pendidikan Indonesia.

[15] Taba, Y.U. (2019). Pengaruh Model Discovery Learning Terhadap Kemampuan Literasi Sains Peserta Didik pada Materi Pokok Ekosistem. Skripsi. Universitas Lampung.

[16] Winarti, W., Liliawati, W., Rusnayati H., dan Sari, I.M. (2016). Literasi Sains Siswa SMP di Kota Bandung pada Tema Alam Semesta. Prosiding Seminar Nasional IPA Pascasarjanan UM. Bandung, Jawa Barat.

[17] Yuliati, Y. (2017). Literasi sains dalam pembelajaran IPA. Jurnal Cakrawala Pendas Vol. 3 No.2: 21-28. 
J. Pijar MIPA, Vol. 15 No.4, September 2020: 339-345

ISSN 1907-1744 (Cetak)

DOI: 10.29303/jpm.v15i4.1957

[18] Hasanah, J., Jamaludin, J., \& Prayitno, G. H. (2019). Bahan Ajar IPA Berbasis Inkuiri Terstruktur Untuk Meningkatkan Literasi Sains Peserta Didik SMP. Jurnal Pijar MIPA, 14(2), 18-24.

[19] Nisrina, N., Jufri, A. W., \& Gunawan, G. (2020). Pengembangan LKPD Berbasis Blended Learning untuk Meningkatkan Literasi Sains Peserta Didik. Jurnal Pijar Mipa, 15(3), 192199. 